\title{
Association mapping for yield and grain quality traits in rice (Oryza sativa L.)
}

Tereza Cristina de Oliveira Borba ${ }^{1}$, Rosana Pereira Vianello Brondani ${ }^{1}$, Flávio Breseghello ${ }^{1}$, Alexandre Siqueira Guedes Coelho ${ }^{2}$, João Antônio Mendonça ${ }^{1}$, Paulo Hideo Nakano Rangel ${ }^{1}$ and Claudio Brondani ${ }^{1}$

${ }^{1}$ Embrapa Arroz e Feijão, Santo Antônio de Goiás, GO, Brazil.

${ }^{2}$ Setor de Melhoramento de Plantas, Escola de Agronomia, Campus-II Samambaia, Universidade Federal de Goiás, Goiânia, GO, Brazil.

\begin{abstract}
Association analysis was applied to a panel of accessions of Embrapa Rice Core Collection (ERiCC) with 86 SSR and field data from two experiments. A clear subdivision between lowland and upland accessions was apparent, thereby indicating the presence of population structure. Thirty-two accessions with admixed ancestry were identified through structure analysis, these being discarded from association analysis, thus leaving 210 accessions subdivided into two panels. The association of yield and grain-quality traits with SSR was undertaken with a mixed linear model, with markers and subpopulation as fixed factors, and kinship matrix as a random factor. Eight markers from the two appraised panels showed significant association with four different traits, although only one (RM190) maintained the marker-trait association across years and cultivation. The significant association detected between amylose content and RM190 was in agreement with previous QTL analyses in the literature. Herein, the feasibility of undertaking association analysis in conjunction with germplasm characterization was demonstrated, even when considering low marker density. The high linkage disequilibrium expected in rice lines and cultivars facilitates the detection of marker-trait associations for implementing marker assisted selection, and the mining of alleles related to important traits in germplasm.
\end{abstract}

Key words: association analysis, core collection, genetic structure.

Received: March 16, 2009; Accepted: February 23, 2010.

\section{Introduction}

Association analysis, or linkage disequilibrium mapping, is a notable strategy used for identifying genes controlling important traits. It is already being successfully applied for identifying genes related to human diseases. Research in humans has turned to association analysis, since linkage analysis has not been successful in the fine-scale mapping of disease loci, due to the impossibility of undertaking controlled-breeding crosses (Flint-Garcia et al., 2003). Unlike humans, in most plant species, the identification of those genomic regions which contribute to important characteristics has been mostly achieved through linkage analysis within segregating populations, the result of crosses between genitors with contrasting phenotypes and genotypes (Buntjer et al., 2005; Skot et al., 2005).

In breeding and pre-breeding programs, QTL detection is an important tool for the identification of favorable alleles and for identifying and validating molecular assisted

Send correspondence to Tereza Cristina de Oliveira Borba. Embrapa Arroz e Feijão, Rodovia GO-462, km 12, Zona Rural, Caixa Postal 179, 75375-000 Santo Antônio de Goiás, GO, Brazil. E-mail: tereza@cnpaf.embrapa.br. selection (MAS). The identification of genomic regions related to quantitative traits in plants was largely achieved through QTL mapping (Skot et al., 2005). However, there are some inherent limitations to QTL analysis. First, in linkage studies, the segregating population usually presents only two segregating alleles per locus, which means that in any given cross, the sampled genetic diversity may be limited. In addition, the potential use of the genetic diversity available in species is restricted (Peleman and van der Voort, 2003). Another disadvantage as regards the substantiation of a low number of traits per cross, is through the difficulty in identifying parents with contrasting genotypes and phenotypes for all those traits of interest (Buntjer et al., 2005). Furthermore, the high resolution desired for MAS or cloning candidate genes requires developing large segregating populations, possibly difficult in some species (Skot et al., 2005).

According to Zondervan and Cardon (2004), the main purpose in linkage analysis, as in association mapping, is the detection of correlations between phenotypic variation and genotypes through linkage disequilibrium. However, association analysis has the advantage of contemplating all the meiotic and recombination events that may occur in the 
evaluated population (Ferreira and Grattapaglia, 2006). Furthermore, this form is highly dependent on the extent of linkage disequilibrium (LD), a higher degree implying the use of less markers per chromosome, without the loss of genetic resolution for marker assisted selection (MAS) (Rostoks et al., 2006). As rice is a self-pollinating species, it is expected to present high linkage disequilibrium (FlintGarcia et al., 2003), thereby requiring fewer markers. In addition, the recent bottlenecks encountered since the beginning of rice breeding have given rise to high linkage disequilibrium blocks, thereby facilitating association studies (Patron et al., 2002).

One of the great advantages of association mapping lies in the fact that no mapping population needs to be developed, as the sampling of non-related individuals represents a series of advantages towards developing and validating MAS in breeding programs (Jannink et al., 2001), as well as an opportunity for increasing the exploitation of germplasm accessions in the search for advantageous allele combinations. Such a strategy, unlike traditional linkage analysis, facilitates the search for functional variation in a much broader germplasm context (Zhu et al., 2008). Thus, experimental populations may constitute a representative sample of a larger population for which inferences are sought (Breseghello and Sorrels, 2006b). In panels with highly divergent individuals and assumed random mating, only polymorphisms with extremely tight linkage to a locus with desirable phenotypic effects are likely to be significantly associated with a given trait (Remington et al., 2001). Furthermore, association analysis can benefit by including data collected over years of experimental analysis with genotypes of breeding programs, with the additional possibility of analyzing several traits simultaneously.

Improving grain yield and quality are important challenges in rice breeding, thus priorities for the international market (Fan et al., 2005). Although quality assumes many aspects and is highly related to preference in diverse cultures, its characteristics are mainly defined by milling properties, grain size and shape, cooking and eating characteristics, and nutritional qualities (He et al., 1999). According to He et al. (1999), of these the most relevant are appearance and cooking quality, reported to be directly related to amylose content, gel consistency and gelatinization temperature (Fan et al., 2005).

The aims of this work were to analyze and identify the association of simple sequence repeat (SSR) markers with yield and grain quality traits in a panel of accessions from the Embrapa Rice Core Collection (ERiCC), represented by breeding material from Brazil and other countries.

\section{Material and Methods}

\section{Plant material and genomic DNA extraction}

The evaluated panel of 242 accessions from ERiCC (Abadie et al., 2005) was composed of: a) 94 accessions of inbred lines and cultivars developed by rice breeding programs in Brazil (57 upland and 37 lowland accessions); and b) 148 accessions of inbred lines and cultivars developed by breeding programs worldwide (76 upland and 72 lowland accessions) (Table S1). Each accession was evaluated in a four-plant bulk, the total genomic DNA being extracted as described by Brondani et al. (2002).

\section{Phenotypic data}

The phenotypic evaluation of 242 ERiCC accessions was carried out in Santo Antônio de Goiás, the state of Goiás, Brazil (altitude $749 \mathrm{~m}$; 16 $16^{\circ} 40^{\prime} 43^{\prime \prime} \mathrm{S}$; $49^{\circ} 15^{\prime} 14^{\prime \prime} \mathrm{W}$ ), in 2004 and 2005 , under irrigated conditions, following an augmented block design with plots of 4 rows $x 5 \mathrm{~m}$, at a density of 20 plants $\mathrm{m}^{-1}$. Data were taken from the two middle rows and the 4 central meters of each. In 2004, the following traits were evaluated: 1) YLD grain yield, in $\mathrm{kg} \mathrm{ha}^{-1} ; 2$ ) TILN - tiller number per plant; and 3) PANN - panicle number per plant. In 2005, two traits were evaluated: YLD and the yield from ratooning (RYLD), this being the yield from the second harvest, approximately 40 days post-main. In both years, grain quality data were evaluated for cooking and milling traits, measured as to amylose content (AC) and head-milled rice (MR), respectively. Amylose content was determined according to Juliano (1979), whereas head-milled rice was measured as the proportion of the weight of whole kernels over the weight of paddy rice. The descriptive statistics of phenotypic data were computed using the Genes 4.1 program (Cruz, 1997).

\section{SSR characterization of ERiCC}

The 86 SSR fluorescent markers were dispersed in all the 12 rice chromosomes, an average of seven markers per chromosome (ranging from a maximum of eight markers and a minimum of five per chromosome). The markers were labeled with the fluorescent dyes HEX (hexachlorine - 6 carboxyfluorescein) and 6-FAM (fluorochrome 6-carboxyfluorescein) (Table S2). PCR was carried out in a final volume of $15 \mu \mathrm{L}$ containing a customized concentration of primers (forward and reverse) (Table S2), $1 \mathrm{X}$ reaction buffer $(50 \mathrm{mM}$ of KCl, $10 \mathrm{mM}$ Tris- $\mathrm{HCl} \mathrm{pH}$ 8.4, 0.1\% Triton $\mathrm{X}-100$ and $1.5 \mathrm{mM}$ of $\mathrm{MgCl} 2), 0.22 \mathrm{mM}$ of dNTP, $15 \mathrm{ng}$ of template DNA, and one unit of the Taq DNA Polymerase enzyme. Thermocycling was carried out in a GeneAmp PCR System 9700 (Applied Biosystems) and the amplification conditions were $94{ }^{\circ} \mathrm{C}$ for 5 min followed by 40 cycles of $94^{\circ} \mathrm{C}$ for $1 \mathrm{~min}$, specific annealing temperature for $1 \mathrm{~min}$, and $72{ }^{\circ} \mathrm{C}$ for $1 \mathrm{~min}$, and a final extension of $72{ }^{\circ} \mathrm{C}$ for $7 \mathrm{~min}$. PCR products were analyzed in an ABI 3100 DNA sequencer (Applied Biosystems) and the alleles were scored with GeneMapper 3.5 software (Applied Biosystems). The size standard used was obtained according to Brondani and Grattapaglia (2001). 


\section{Statistical analysis}

Allele diversity and genetic structure: The 242 inbred lines and cultivars of ERiCC were analyzed in a pooled DNA sample, composed of four individual plants. From SSR analysis, heterogeneity (the presence of individual heterozygous or homozygous plants with different alleles in the bulk) was evident in certain accessions. In order to proceed with association analysis, the accessions were treated as pure lines, under the definition of working alleles, and represented by the most common allele. Rare alleles (frequency below 5\%) were treated as missing data in population structure analysis, and as null alleles in association analysis, according to the strategy described by Breseghello and Sorrels (2006a). The hypothesis of division from one to four subpopulations was tested with structure software (Pritchard et al., 2000), allowing for admixture and correlated allele frequencies, with a burn-in of 10,000 and a run-length of 100,000. The Fst parameter (software FSTAT 2.9.3.2; Goudet, 2002) and factorial correspondence analysis (FCA) (software Genetix 4.03; Belkhir et $a l ., 2004)$ were also applied for investigating accession genetic structure.

Association analysis: The association between markers and phenotypic traits was done using the Mixed Linear Model (MLM), an available option in Tassel version 1.9.6 software, where markers tested and subpopulation data (Q matrix) were considered as fixed-effect factors, whereas the kinship matrix was considered as a random-effect factor. The kinship matrix was obtained from SPAGeDi version 1.2 software (Hardy and Vekemans, 2002). To confirm the significance of associations between loci and traits, a correction for multiple testing was applied using the false discovery rate (FDR) method with Qvalue version 1.0 software (Storey, 2002). The FDR level was set at 0.05, and the $\pi_{0}$ method for bootstrap analysis. The FDR method, expressed as a $q$-value, is defined as the expected proportion of true null hypotheses within the class of rejected null hypotheses (Kraakman et al., 2004).

The significance of differences between allele effects was obtained from Kruskal-Wallis nonparametric rank testing with $R$ program ( $R$ Development Core Team). Nonparametrical multiple test procedures, regarding amylose content and each pair of alleles, were carried out as described by Campos (1983).

\section{Results}

\section{Phenotypic data}

Experimental field data were distributed normally, except for traits related to grain quality (AC and MR). ERiCC accessions revealed wide variation in performance of all the evaluated traits (Table 1). In the 2004 experiment, the firmest correlation detected was between TILN and PANN $(0.88 ; \mathrm{p}<0.01)$, and in the 2005, between YLD and $\operatorname{MR}(0.38 ; \mathrm{p}<0.01)$ (Table 2). No correlation was detected in yield data from 2004 and 2005 experiments.

\section{Allele diversity and population structure}

A total of 1,066 alleles were detected with the set of 86 SSR markers on a panel of 242 accessions. The average number of alleles per locus was 12.4, ranging from three (RM484) to 32 (RM204). Most loci presented one or more alleles with a frequency below $5 \%$. These rare alleles represented, approximately, $48 \%$ of the total allele number, and to avoid an increase in variance errors in association analysis, they were not considered. The remaining alleles (554), referred to as common alleles, ranged from two to eight per locus. In lowland accessions, the mean was 4.80 alleles per locus, with gene diversity of 0.64 , whereas in upland accessions this was 4.76 alleles per locus and gene diversity 0.56 . Common SSR alleles were used to check the structure of ERiCC genetic variation. The model-based clustering method resulted in the highest likelihood from data, i.e. the

Table 1 - Descriptive statistics for yield (YLD), tiller number (TILN), panicle number (PANN), yield from ratooning (RYLD), amylose content (AC) and head-milled rice (MR).

\begin{tabular}{|c|c|c|c|c|c|c|c|c|c|}
\hline & \multicolumn{5}{|c|}{2004 Experiment } & \multicolumn{4}{|c|}{2005 Experiment } \\
\hline & $\begin{array}{c}\text { YLD } \\
(\mathrm{kg} / \mathrm{ha})\end{array}$ & TILN & PANN & $\begin{array}{l}\mathrm{AC} \\
(\%)\end{array}$ & $\begin{array}{l}\text { MR } \\
(\%)\end{array}$ & $\begin{array}{c}\text { YLD } \\
(\mathrm{kg} / \mathrm{ha})\end{array}$ & $\begin{array}{l}\text { RYLD } \\
\text { (kg/ha) }\end{array}$ & $\begin{array}{l}\mathrm{AC} \\
(\%)\end{array}$ & $\begin{array}{l}\mathrm{MR} \\
(\%)\end{array}$ \\
\hline Average & 4685.0 & 166.43 & 143.3 & 24.3 & 60.4 & 4298.1 & 1403.4 & 24.1 & 43.1 \\
\hline Minimum & 900 & 71 & 32 & 4 & 42.0 & 435 & 0 & 8 & 3.57 \\
\hline Maximum & 8844 & 281 & 236 & 31 & 70.9 & 8130 & 3020 & 31 & 66.1 \\
\hline Standard deviation & 41.6 & 6.7 & 6.2 & 2.5 & 2.5 & 39.0 & 24.4 & 2.2 & 3.8 \\
\hline BR IRGA $409^{\#}$ & 5993.5 & 154 & 128 & 27 & 65.1 & 5372.3 & 1425.7 & 26 & 46.9 \\
\hline CAIAPO $^{\#}$ & 2948.7 & 114 & 102 & 26 & - & 5720.2 & 1125.0 & 24 & 61.9 \\
\hline METICA $1^{\#}$ & 6243.5 & 197 & 175 & 25 & - & 3282.9 & 1884.2 & 25 & 43.17 \\
\hline COLOSSO $^{\#}$ & 3911.1 & 127 & 108 & 25 & - & 4785.0 & 1350.0 & 24 & 65.4 \\
\hline
\end{tabular}

\footnotetext{
${ }^{\#}$ Controls of field experiments for both years.
} 
Table 2 - Pearson correlation coefficients among the phenotypic traits: yield (YLD), tiller number (TILN), panicle number (PANN), yield from ratooning (RYLD), amylose content (AC) and head-milled rice (MR).

\begin{tabular}{|c|c|c|c|c|c|c|c|c|c|c|}
\hline & & \multicolumn{5}{|c|}{2004 Experiment } & \multicolumn{4}{|c|}{2005 Experiment } \\
\hline & & $\begin{array}{l}\text { YLD } \\
(\mathrm{kg} / \mathrm{ha})\end{array}$ & TILN & PANN & $\begin{array}{l}\mathrm{AC} \\
(\%)\end{array}$ & $\begin{array}{l}\text { MR } \\
(\%)\end{array}$ & $\begin{array}{l}\text { YLD } \\
(\mathrm{kg} / \mathrm{ha})\end{array}$ & $\begin{array}{l}\text { RYLD } \\
\text { (kg/ha) }\end{array}$ & $\begin{array}{l}\mathrm{AC} \\
(\%)\end{array}$ & $\begin{array}{l}\text { MR } \\
(\%)\end{array}$ \\
\hline \multirow{5}{*}{$\begin{array}{l}2004 \\
\text { Experiment }\end{array}$} & YLD & - & & & & & & & & \\
\hline & TILN & $0.20 * *$ & & & & & & & & \\
\hline & PANN & $0.31 * *$ & $0.88 * *$ & & & & & & & \\
\hline & $\mathrm{AC}$ & $0.19 * *$ & $0.26 * *$ & $0.25 * *$ & & & & & & \\
\hline & MR & $0.31 * *$ & - & - & - & & & & & \\
\hline \multirow{4}{*}{$\begin{array}{l}2005 \\
\text { Experiment }\end{array}$} & YLD & - & - & - & - & - & & & & \\
\hline & RYLD & - & - & - & - & - & - & & & \\
\hline & $\mathrm{AC}$ & - & - & - & $0.82 * *$ & - & $0.20 * *$ & $0.26^{* *}$ & & \\
\hline & MR & - & - & - & - & $0.14 *$ & $0.38 * *$ & - & - & - \\
\hline
\end{tabular}

Only significant values are shown $(* \mathrm{p}<0.05 ; * * \mathrm{p}<0.01)$.

probability that a given individual originated from a certain population, when the number of subpopulations (k) was set at 2 , thereby indicating a subdivision among accessions caused by the cultivation system (lowland or upland rice accessions). No population structure was detected due to the origin of accessions (Brazilian or worldwide breeding programs).

Thirty-two accessions (13\%) were predicted to have admixed ancestry, this meaning that their origin could not be attributed exclusively to one of the two inferred subpopulations. Consequently, they were discarded from the analysis. Association analysis was then undertaken with 210 ERiCC accessions (92 lowland and 118 upland). The overall Fst statistics across subpopulations was 0.775 , and $F s t$ values for lowland and upland groups were 0.135 and 0.205 , respectively, thereby indicating high differentiation among subpopulations, and low to intermediate levels of differentiation within accessions from the same subpopulation. FCA was applied in order to visualize the subdivision among accessions, whereby it was possible to confirm the division into two subpopulations, based on the cultivation system (Figure 1).

\section{Association analysis}

Three different accession panels, viz., a complete panel of 210 accessions, and from this, 92 lowland accessions and 118 upland, were analyzed (association analysis). 23 SSR markers $(27 \%)$ in the complete panel were identified as being significantly associated to at least one of the evaluated traits (data not shown). On considering the low genomic coverage of the SSR set, and the complexity of the traits evaluated, the number of associated markers was high, thereby implying the presence of spurious markertrait associations. On considering the system of cultivation

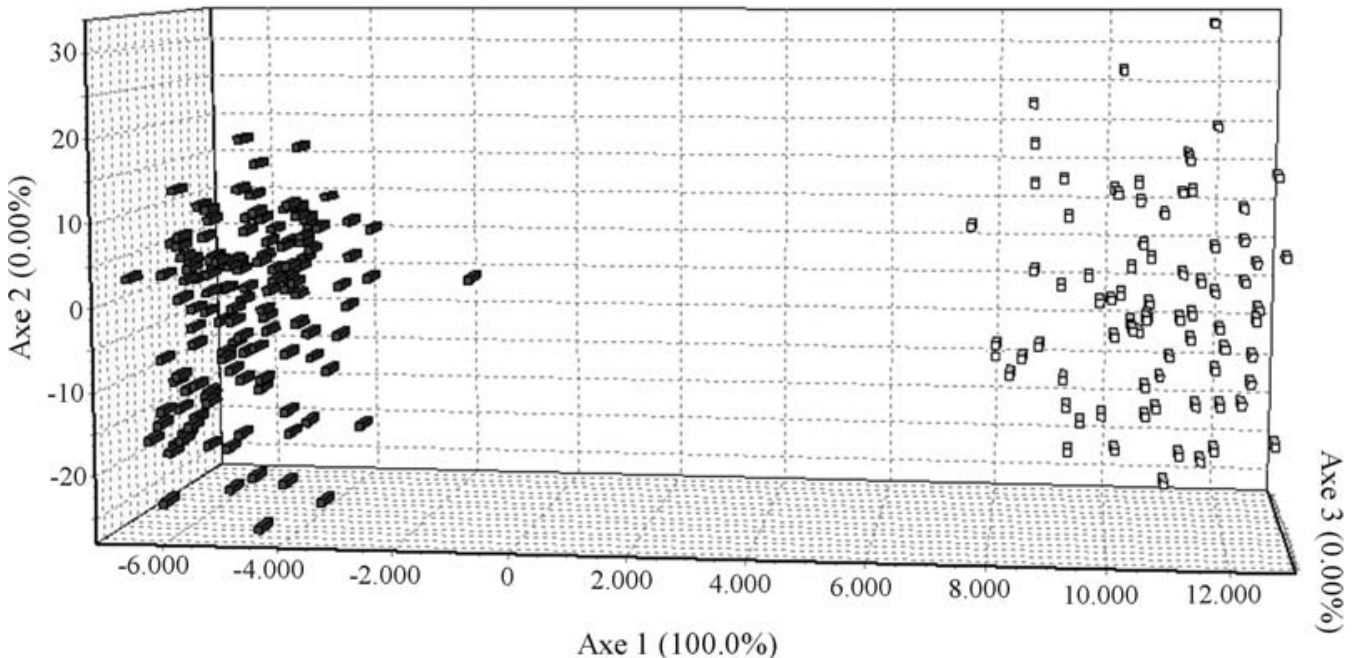

Figure 1 - Spatial distribution of genetic variability in the 210 selected accessions from ERiCC, based on factorial correspondence analysis (FCA). The white dots represent lowland accessions and the gray, uplandones. 
as the main generator of genetic structuring among all the 210 accessions, and using subpopulations as a basis for re-analysis, two accession panels were defined, with a lower number of marker-trait associations. From the 86 SSRs, eight markers were associated with four traits in lowland, and only one with amylose content in upland accessions (Table 3). In lowland accessions, the marker OG60 was associated with PANN in the 2004 experiment and RM190 with AC in both the 2004 and 2005. In 2005, two markers (RM1 and 4653) were associated with MR, and four (RM264, RM267, RM125 and RM38) with YLD. In upland accessions and in both years, there was a significant association of only RM190 with AC. There was no association with any marker in the case of RYLD and TILN. Despite the significant associations between marker-trait, the only consistent association over years and cropping systems was between the RM190 marker and AC. This association was also significant in the analysis of all the 210 accessions (data not shown).

On considering the 210 accessions, six alleles (frequencies over 5\%) were distinguished for RM190, with four common in both accession panels (alleles 105, 107, 121 and $125 \mathrm{bp}$ ). However, two alleles (117 and $119 \mathrm{bp}$ ) were identified (frequencies over 5\%) one each only in upland and lowland accession panels, respectively (Figure 2). From Kruskal-Wallis testing, it was possible to identify a significant difference in allele effects across lowland and upland panel accessions From a multiple test based on a nonparametrical approach it was possible to identify the relationships of the six RM190 alleles with diverse classes of amylose content, as well as positive and significant correlation, for both years, in upland and lowland panel accessions ( 0.58 with $\mathrm{p}<0.01$, and 0.54 with $\mathrm{p}<0.01$, respectively).

In the lowland accession panel, the 105 and $107 \mathrm{bp}$ (base pair) alleles presented significantly different effects from the remainder. According to 2004 and 2005 experi- mental data, both were correlated to higher amylose content than the others, although in 2004, there was a significant difference between the two themselves, with the 105 bp revealing higher AC than the $107 \mathrm{bp}$ (Table 4). Despite statistical differences between AC and the respective alleles, no clear pattern in allele effects could be identified in lowland accessions. In the upland accession panel, both in 2004 and 2005, $121 \mathrm{bp}$ allele AC was lower than in 105, 107 and $125 \mathrm{bp}$, whereas in 2005, 117 bp allele AC was lower than in 105 and 107 bp. As with lowland accessions, no clear pattern in allele effects was identified.

\section{Discussion}

\section{SSR allele diversity and population structure}

A set of 86 highly informative SSR markers was used in genotyping ERiCC inbred lines and cultivars. The number of common alleles detected (frequency $\geq 5 \%$ ) was similar to that previously identified for inbred rice lines and cultivars (Lu et al., 2005). In the present work, rare alleles were not integrated into analysis, as low frequency alleles inflate variance estimates of linkage disequilibrium (Remington et al., 2001). Additionally, rare alleles are more susceptible to bias caused by covariance between markers and population structure, thus increasing the chance of type I error (Breseghello and Sorrels, 2006a). The presence of admixture also contributes to overestimating linkage disequilibrium, due to causes not related to physical connections on a chromosome (Flint-Garcia et al., 2003).

According to Breseghello and Sorrels (2006a), the selection process of a minimum sample with maximum variation results in a normalizing effect that is expected to minimize population structure, thereby creating a favorable situation for association analysis. Structure-presence specification is a prior requirement in core collections, since certain procedures adopted to build these collections may lead

Table 3 - Association of SSR markers with phenotypic traits. The statistics shown refer to the coefficient of determination $\left(\mathrm{R}^{2}\right)$.

\begin{tabular}{|c|c|c|c|c|c|c|c|}
\hline & \multirow[t]{2}{*}{ Marker } & \multirow[t]{2}{*}{ Chromosome } & \multicolumn{2}{|c|}{ Experiment 2004} & \multicolumn{3}{|c|}{ Experiment 2005} \\
\hline & & & PANN & $\mathrm{AC}$ & MR & YLD & $\mathrm{AC}$ \\
\hline \multirow{6}{*}{ Lowland accessions } & RM38 & 8 & 0.083 & 0.049 & 0.021 & $0.040 *(q)$ & 0.074 \\
\hline & RM125 & 7 & 0.039 & 0.040 & 0.037 & $0.002 *(q)$ & 0.000 \\
\hline & RM264 & 8 & 0.000 & 0.170 & 0.027 & $0.001 *(q)$ & 0.110 \\
\hline & RM267 & 5 & 0.020 & 0.019 & 0.020 & $0.011 *(q)$ & 0.035 \\
\hline & 4653 & 12 & 0.137 & 0.068 & $0.004 *(q)$ & 0.143 & 0.070 \\
\hline & OG60 & 4 & $0.352 *(q)$ & 0.023 & 0.053 & 0.000 & 0.204 \\
\hline Upland accessions & RM190 & 6 & 0.000 & $0.390 * *(q)$ & 0.000 & 0.090 & $0.490 * *(q)$ \\
\hline
\end{tabular}

Panicle number (PANN); amylose content (AC); head-milled rice (MR); yield (YLD).

Only SSR markers with significant marker-trait association are given. The $q$ indicates the false discovery rate control value set to 0.05 . $* \mathrm{p}<0.005$; $* * \mathrm{p}<0.0001$. 
to a structured accession panel. The stratification of accessions into meaningful groups, with the maximum variation between groups and the minimum within, as suggested by van Hintum et al. (2000), may result in accession panels with low potential for detecting gene effects through association analysis, since most variance is attributed to population structure. ERiCC inbred lines and cultivars were origi-
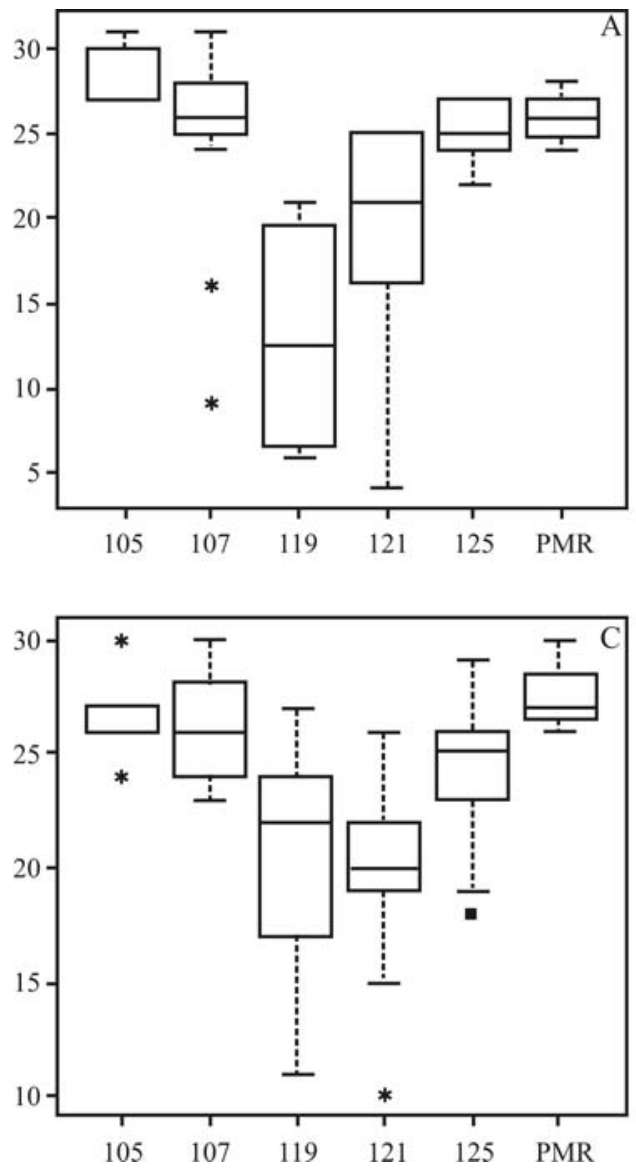

nally selected according to the origin of accessions (Brazil or worldwide breeding programs), and their system of cultivation (lowland or upland) (Abadie et al., 2005). The ERiCC structure based on a cultivation system is probably due to most lowland accessions being from indica subspecies, whereas upland accessions are mostly from japonica (Khush, 1997).
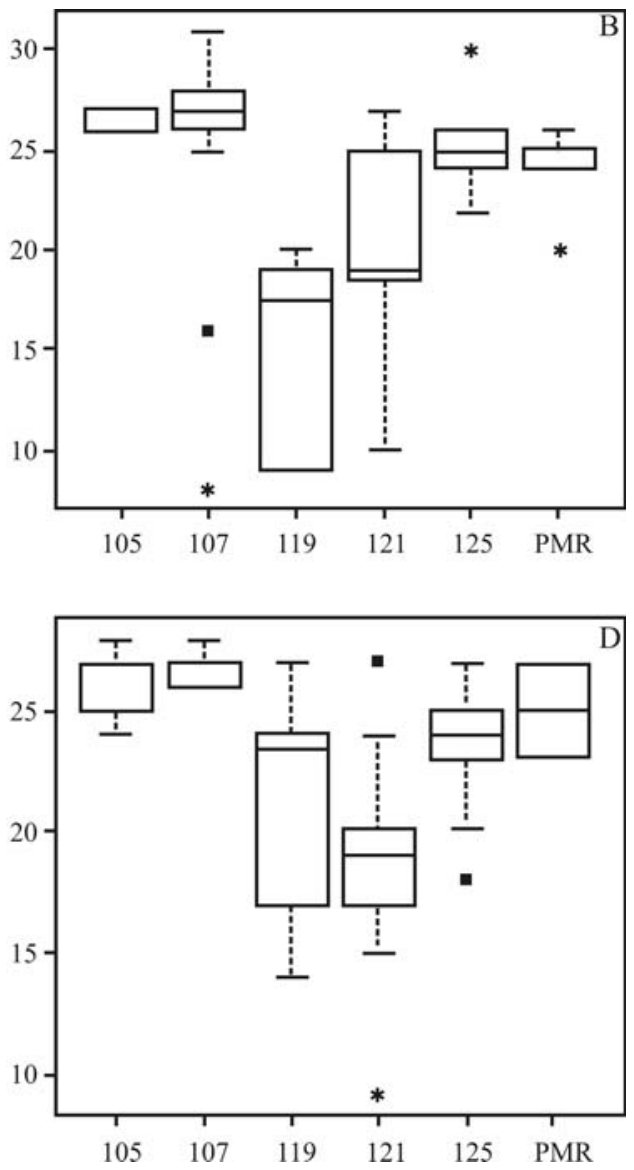

Figure 2 - Empirical distribution of amylose content ( $y$-axis) among alleles identified for RM190 SSR ( $x$-axis). The subdivisions in amylose content data refer to quartile division, and the lines in boxes are the median of amylose content in each allele. The $\mathrm{A}$ and $\mathrm{B}$ boxes refer to amylose content data on lowland accessions from the 2004 and 2005 experiments, respectively. The $\mathrm{C}$ and D boxes refer to amylose content data on upland accessions from the 2004 and 2005 experiments, respectively. The pool of rare and missing alleles is represented by the PMR denominated allele.

Table 4 - Pairwise statistical differences in average amylose content values of each identified allele of the RM190 marker in both accession panels and over experimental years.

\begin{tabular}{lcccccc}
\hline & 105 & 107 & 117 & 119 & 121 & 125 \\
\hline 105 & - & & & & \\
107 & $\mathrm{~L} / 04$ & - & & & \\
117 & $\mathrm{U} / 05$ & $\mathrm{U} / 05$ & - & & \\
119 & $\mathrm{~L} / 04, \mathrm{~L} / 05$ & $\mathrm{~L} / 04, \mathrm{~L} / 05$ & - & - & - \\
121 & $\mathrm{~L} / 04, \mathrm{U} / 04, \mathrm{U} / 05$ & $\mathrm{~L} / 04, \mathrm{~L} / 05, \mathrm{U} / 04, \mathrm{U} / 05$ & - & - & - & - \\
125 & $\mathrm{~L} / 04$ & $\mathrm{~L} / 05$ & - & - & $\mathrm{U} / 04, \mathrm{U} / 05$ & - \\
$\mathrm{PMR}$ & - & - & - & - & $\mathrm{U} / 04$ & - \\
\hline
\end{tabular}

L - Lowland accession panel. U - Upland accession panel. 04 - Data from 2004 experiment. 05 - Data from 2005 experiment. PMR - pool of missing and rare alleles for the RM190 marker. 
A very substantial differentiation between lowland and upland accessions was identified, after the removal of rare alleles and admixed accessions, with Fst increasing from 0.11 to 0.77 . In Garris et al. (2005), Fst values for indica and temperate japonica and indica and tropical japonica accessions were, respectively, 0.43 and 0.36 , with the proportion of admixed ancestry estimated at $10 \%$. The higher Fst value identified between lowland and upland accession panels, even when compared to the divergent indica and japonica accessions found by Garris et al. (2005), may be due to the elimination of rare alleles and accessions with mixed ancestry, thereby increasing divergence between the two.

\section{Association analysis}

Despite the broad genome coverage provided by the set of 86 SSR markers used in the analysis, the whole genome scan designed for association analysis was limited by the low density of markers. However, due to numerous bottlenecks in the history of rice domestication, the level of linkage disequilibrium in some regions is estimated to be greater than the $250 \mathrm{~kb}$ found in Arabidopsis (Garris et al., 2003). Considering this situation, a target marker can be associated to a candidate gene responsible for certain traits, even though thousands of base pairs apart, thereby favoring marker-assisted selection procedures.

Association analysis with MLM combines information from kinship and population structure, thereby reducing type I errors (Yu et al., 2006), that is the error of rejecting a null hypothesis when it is actually true. Here, 23 SSR markers, associated to yield and grain quality traits, were identified, when such an approach was applied to the panel of 210 accessions. Agrama et al. (2007), on using the same model in association analysis of yields and their components in 103 rice germplasm accessions with 123 SSR markers, identified 25 marker-trait associations with 21 SSRs. The main subpopulations identified from their data set corresponded to the geographic origin of accessions. However, from our results there was every indication that the subdivision of the evaluated accessions could be attributed to differences in the cultivation system. In the case of Agrama et al. (2007), the difference could be due to bias in favor of japonica as against indica accessions, for, from the 103 rice accessions, 49 corresponded to japonica accessions, whereas 25 were classified as of an admixed ancestry, mainly between those with an indica and temperate japonica background.

In a comparative analysis of yield components, with data from 2004 and 2005, a difference was noted, from one year to the next, in the marker-trait association of yieldrelated genes, as detected by SSR markers. Quantitative agronomic traits, such as yield, are especially affected by the interaction of both genotype and environment, an understanding of how this interaction is controlled being a basis for defining breeding strategies that would improve genetic gains within these traits.

Two markers (RM38 and RM267) were previously detected by QTL mapping. RM38 was related to yield when assaying 190 lines in an indica x japonica double-haploid population, genotyped with 179 SSR markers for agronomic traits in a two-year replicated-field experiment (Jiang et al., 2004). This finding was corroborated by Marri et al. (2005) who also found the RM38 marker related to a yield QTL ( $\mathrm{R}^{2}$ of 7.99), by using an interspecific population of 251 advanced backcross families (O. rufipogon x $O$. sativa), genotyped with 80 SSR markers. Cho et al. (2003) identified the association of RM267 with a yield QTL detected in an interspecific backcross $\mathrm{F}_{2}$ population $(O$. rufipogon $\mathrm{x} O$. sativa). A recent study in rice, dealt with the association between markers previously identified as linked at QTLs (Agrama et al., 2007). With this base, QTL analysis can be considered a pre-requisite for distinguishing markers related to important traits, by constituting, together with complementary association studies using highly divergent accession panels from core collections, a means of identifying the different alleles of these markers and attributing phenotypic weights to each.

No difference in allelic effects on yield was identified through association analysis, when considering markers previously associated to this trait in rice. This may be due to the complex inheritance of the YLD trait, as not only a single allele, but also epistatic alleles are involved. Haplotypes related to highest performance may be identified through association analysis, and, an additional advantage over QTL mapping analysis, values can be attributed to alleles present in a given panel of individuals, whereby the most favorable combinations can be traced by breeders in all elite lines and cultivars. Consequentially, there is an increase in the capacity of novel sets in detecting marker-trait associations, even of alleles with minor or modest phenotypic effects (Risch and Zhang, 1996). In QTL linkage analysis, on the contrary, only a maximum of two alleles per locus are involved (diploid individual), with detection being restricted to the size of the effect and the presence of contrasts between genitor alleles in the desired trait.

As to grain quality traits, RM1 was associated to MR in the 2005 field experiment, and to yield QTL in previous works (Yu et al., 1997; Brondani et al., 2002; Septiningsih et al., 2003), thereby indicating its location in a genomic region, and thus requiring detailed analysis, in order to identify genes and alleles of agronomic interest. In Brazil, rice breeders consider MR to be a very important trait, since cultivars, wherein the percentage of intact grains falls below $60 \%$, are considered to be economically of less value. As to RM190 (Waxy gene), which is related to expression of the granule-bound starch-synthase enzyme, and is largely responsible for amylose content in rice grains (Ayres et al., 1997), association to AC was reported in seven different segregating populations when applying QTL linkage 
analysis (He et al., 1999; Tan et al., 1999; Lanceras et al., 2000; Septiningsih et al., 2003; Zhou et al., 2003; Aluko et al., 2004; Fan et al., 2005). AC was significantly related to RM190 through association analysis in both panels of upland and lowland accessions, throughout the two years.

The confirmation of an association between the RM190 marker and AC, when using core collection accessions, is additional evidence of efficiency in applying association analysis to gene identification. The significant results from Kruskal-Wallis testing, comprising experimental years and accession panels, implies that at least one of the alleles, exerted a discriminating effect on amylose content. Nevertheless, in spite of the lack of complete correspondence between RM190 alleles and amylose content, as to experimental-year and accession panel, some indication of a correlation for alleles 105 and $107 \mathrm{bp}$ to intermediate amylose content, in the panel of lowland accessions and by experimental year, was found. On evaluating a panel of 89 non-waxy accessions, Ayres et al. (1997) identified seven alleles from a SSR marker in the $W x$ gene, whence four were correlated with different patterns of amylose content (high, intermediate and low), thus defining approximately $83 \%$ of AC variation. Bao et al. (2006) when examining a panel of 499 non-waxy accessions with RM190, identified ten alleles that together accounted for nearly $90 \%$ of AC variation. The difference of allelic correlation to amylose content classes recorded in the present work, Ayres et al. (1997) and Bao et al. (2006), could be due to the different composition of accession panels, since Ayres et al. (1997) analyzed a set of rice accessions from the U.S.A. with a narrower genetic base when compared to the ERiCC accession panel. Bao et al. (2006), when comparing the ERiCC accession panel, analyzed a panel of germplasm accessions with low diversity for the Waxy SSR marker, since from the ten alleles identified, only two accounted for a frequency of approximately $83 \%$. The evaluation of germplasm accessions with a narrower genetic basis may be reflected in a low variation in modifier genes that could influence AC, particularly at the Waxy locus. This low variation in rice genomes, even in traits controlled by epistatic alleles, may restrict phenotypic trait variability. On the other hand, a wider genetic basis, as found in ERiCC accessions, could increase AC phenotypic variation, due to the allelic variability in genes located upstream of the Waxy gene in the starch synthesis route. This would reduce the power of a marker assisted selection in pre-breeding and breeding programs, if based solely on Waxy gene alleles, thereby requiring, as mandatory, the study of allelic variation in transcripts from the starch synthesis route in rice grains. As with Ayres et al. (1997), RM190 alleles with no relation to any specific class of amylose content were observed in the present work.

Starch makes up for $90 \%$ of polished grain in rice, and $\mathrm{AC}$ is recognized as one of the most important components in rice grain products (Bao et al., 2006). The use of marker assisted selection for this trait would be of help in breeding programs, since accessions could be genotyped at an early stage for a trait that is normally evaluated after harvesting. However, the lack of correspondence in RM190 alleles to specific AC classes, as well as rice accessions with similar AC values, maybe showing differences in rice eating and textural qualities (Bao et al., 2006), indicate the need for further studies before MAS implementation. Currently in the Embrapa breeding program, AC analysis is an annual, routine procedure in hundreds of inbred lines. In advanced elite inbred lines, the result of this analysis is being correlated with the direct determination of gel consistency and pasting viscosity by a panel of trained panelists, by using a small quantity of grains cooked in Petri dishes, thereby providing precise standards for defining grain quality.

This study demonstrated the feasibility of conducting association analysis together with germplasm characterization of a rice core collection using SSR markers. It also facilitated the identification of markers related to yield, panicle number, milled-head rice and amylose content, in a panel of genetically unrelated ERiCC accessions. Quantitative traits, such as yield, have complex gene and allele interactions, and studies to dissect this trait may start from QTL analysis, due to consolidated statistics and higher resolution potential. The expected high linkage disequilibrium of rice inbred lines and cultivars, although facilitating the detection of marker-trait associations, makes gene identification more difficult, since LD spans many thousands of base pairs. However, for breeding purposes the correlations detected by association analysis may be sufficient for marker assisted selection and mining alleles related to important traits in germplasm collections.

\section{Acknowledgments}

We gratefully acknowledge the Ph.D. scholarship for Tereza Borba and financial support from CNPq.

\section{References}

Abadie T, Cordeiro CMT, Fonseca JR, Alves RBN, Burle ML, Brondani C, Rangel PHN, Castro EM, Silva HT, Freire MS, et al. (2005) Constructing a rice core collection for Brazil. Pesq Agropec Bras 40:129-136.

Agrama HA, Eizenga GC and Yan W (2007) Association mapping of yield and its components in rice cultivars. Mol Breed 19:341-356.

Aluko G, Martinez C, Tohme J, Castano C, Bergman C and Oard JH (2004) QTL mapping of grain quality traits from the interspecific cross Oryza sativa $x$ O. glaberrima. Theor Appl Genet 109:630-639.

Ayres NM, McClung A, Larkin PD, Bligh HFJ, Jones CA and Park WD (1997) Microsatellites and a single nucleotide polymorphism differentiate apparent amylose classes in an extended pedigree of US rice germplasm. Theor Appl Genet 94:773-781.

Bao JS, Corke H and Sun M (2006) Microsatellites, single nucleotide polymorphisms and a sequence tagged site in starch- 
synthesizing genes in relation to starch physicochemical properties in nonwaxy rice (Oryza sativa L.). Theor Appl Genet 113:1185-1196.

Breseghello F and Sorrels ME (2006a) Association mapping of kernel size and milling quality in wheat (Triticum aestivum L.) cultivars. Genetics 172:1165-1177.

Breseghello F and Sorrels ME (2006b) Association analysis as a strategy for improvement of qualitative traits in plants. Crop Sci 46:1323-1330.

Brondani C, Rangel PHN, Brondani RPV and Ferreira ME (2002) QTL mapping and introgression of yield related traits from Oryza glumaepatula to cultivated rice (Oryza sativa) using microsatellite markers. Theor Appl Genet 104:1192-1203.

Brondani RPV and Grattapaglia D (2001) Cost-effective method to synthesize a fluorescent internal DNA standard for automated fragment sizing. Biotechniques 31:793-800.

Buntjer JB, Sorensen AP and Peleman JD (2005) Haplotype diversity: The link between statistical and biological association. Trends Plant Sci 10:466-471.

Campos H (1983) Estatística Experimental Não-Paramétrica. $4^{\mathrm{a}}$ edição. ESALQ, Piracicaba, 349 pp.

Cho YC, Suh JP, Choi IS, Hong HC, Baek MK, Kang KH, Kim YG, Ahn SN, Choi HC, Hwang HG, et al. (2003) QTLs analysis of yield and its related traits in wild rice relative Oryza rufipogon. Treat Crop Res 4:19-29.

Cruz CD (1997) Programa Genes: Aplicativo Computacional em Genética e Estatística. $1^{\mathrm{a}}$ edição. Editora UFV, Viçosa, 442 pp.

Fan CC, Yu XQ, Xing YZ, Xu CG, Luo LJ and Zhang Q (2005) The main effects, epistatic effects and environmental interactions of QTLs on the cooking and eating quality of rice in a doubled-haploid line population. Theor Appl Genet 110:1445-1452.

Ferreira ME and Grattaplaglia D (2006) Genética de associação em plantas. In: Borém A and Caixeta, ET (eds) Marcadores Moleculares. Editora UFV, Viçosa, pp 273-306.

Flint-Garcia AS, Thornsberry JM and Buckler ES (2003) Structure of linkage disequilibrium in plants. Annu Rev Plant Biol 54:357-374.

Garris AJ, McCouch SR and Kresovich S (2003) Population structure and its effect on haplotype diversity and linkage disequilibrium surrounding the xa5 locus of rice (Oryza sativa L.). Genetics 165:759-769.

Garris AJ, Tai TH, Coburn J, Kresovich S and McCouch S (2005) Genetic structure and diversity in Oryza sativa L. Genetics 169:1631-1638.

Hardy OJ and Vekemans X (2002) SPAGeDi: A versatile computer program to analyse spatial genetic structure at the individual or population levels. Mol Ecol Notes 2:618-620.

He P, Li SG, Qian Q, Ma YQ, Li JZ, Wang WM, Chen Y and Zhu LH (1999) Genetic analysis of rice grain quality. Theor Appl Genet 98:502-508.

Jannink JL, Bink CAMM and Jansen RC (2001) Using complex plant pedigrees to map valuable genes. Trends Plant Sci 6:337-342.

Jiang GH, Xu CG, Li XH and He YQ (2004) Characterization of the genetic basis for yield and its component traits of rice revealed by doubled haploid population. Yi Chuan Xue Bao 31:63-72.

Juliano B (1979) Amylose analysis - A review. In: Chemical Aspects of Rice Grain Quality. IRRI, Los Banõs, pp 251-260.
Khush GS (1997) Origin, dispersal, cultivation and variation of rice. Plant Mol Biol 35:25-34.

Kraakman ATW, Niks RF, van den Berg PMMM, Stam P and van Eeuwijk FA (2004) Linkage disequilibrium of yield and yield stability in modern spring barley cultivars. Genetics 168:435-446.

Lanceras JC, Huang ZL, Naivikul O, Vanavichit A, Ruanjaichon $\mathrm{V}$ and Tragoonrung S (2000) Mapping of genes for cooking and eating qualities in Thai jasmine rice (KDML105). DNA Res 7:93-101.

Lu H, Redus MA, Coburn JR, Rutger JN, McCouch SR and Tai TH (2005) Population structure and breeding patterns of 145 U.S. rice cultivars based on SSR marker analysis. Crop Sci 45:66-76.

Marri PR, Sarla N, Reddy LV and Siddiq EA (2005) Identification and mapping of yield and yield related QTLs from an Indian accession of Oryza rufipogon. BMC Genet 6:1-14.

Patron NJ, Smith AM, Fahy BF, Hylton CM, Naldrett MJ, Rossnagel BG and Denyer K (2002) The altered pattern of amylose accumulation in the endosperm of low-amylose barley cultivars is attributable to a single mutant allele of granule-bound starch synthase I with a deletion in the 5'non-coding region. Plant Physiol 130:190-198.

Peleman JD and van der Voort JR (2003) Breeding by design. Trends Plant Sci 8:330-334.

Pritchard JK, Stephens M and Donnelly P (2000) Inference of population structure using multilocus genotype data. Genetics 155:945-959.

Remington DL, Thornsberry JM, Matsuoka Y, Wilson LM, Whitt SR, Doebley J, Kresovich S, Goodman MM and Buckler ES (2001) Structure of linkage disequilibrium and phenotypic associations in the maize genome. Proc Natl Acad Sci USA 98:11479-11484.

Risch N and Zhang H (1996) Mapping quantitative trait loci with extreme discordant pairs, sampling considerations. Am J Hum Genet 58:836-843.

Rostoks NT, Ramsay L, Mackenzie K, Cardle L, Bhat PR, Roose ML, Svensson JT, Stein N, Varshney RK, Marshall DF, et al. (2006). Recent history of artificial outcrossing facilitates whole-genome association mapping in elite inbred crop varieties. Proc Natl Acad Sci USA 103:18656-18661.

Septiningsih EM, Prasetiyono J, Lubis E, Tai TH, Tjubaryat T, Moeljopawiro S and McCouch S (2003) Identification of quantitative trait loci for yield and yield components in an advanced backcross population derived from the Oryza sativa variety IR64 and the wild relative $O$. rufipogon. Theor Appl Genet 107:1419-1432.

Skot L, Humphreys MO and Armstead I (2005) An association mapping approach to identify flowering time genes in natural populations of Lolium perenne (L.). Mol Breed 15:233245.

Storey JD (2002) A direct approach to false discovery rates. J R Stat Soc Ser B 64:479-498.

Tan YF, Li JX, Yu SB, Xing YZ, Xu CG and Zhang Q (1999) The three important traits for cooking and eating quality of rice grains are controlled by a single locus in na elite rice hybrid, Shanyou 63. Theor Appl Genet 99:642-648.

Yu JG, Pressoir WH, Briggs I, Bi IV, Yamasaki M, Doebley JF, McMullen MD, Gaut BS, Nielsen DM, Holland JB, et al. (2006) A unified mixed-model method for association map- 
ping that accounts for multiple levels of relatedness. Nat Genet 38:203-208.

Yu SB, Li JX, Xu CG, Tan YF, Gao YJ, Li XH, Zhang Q and Maroof MAS (1997) Importance of epistasis as the genetic basis of heterosis in an elite rice hybrid. Proc Natl Acad Sci USA 94:9226-9231.

Zhou PH, Tan YF, He YQ, Xu C and Zhang Q (2003) Simultaneous improvement for four quality traits of Zhenshan 97, an elite parent of hybrid rice, by molecular marker-assisted selection. Theor Appl Genet 106:326-331.

Zhu C, Gore M, Buckler ES and Yu J (2008) Status and prospects of association mapping in plants. Plant Genome 1:5-20.

Zondervan KT and Cardon LR (2004) The complex interplay among factors that influence allelic association. Nat Rev Genet 5:89-100.

\section{Internet Resources}

Belkhir K, Borsa P and Chikhi L (2001) Genetix v. 4.05.2. Université de Montpellier. http://www.univ-montp2.fr/ genetix/genetix/genetix.htm (May 5, 2004).
Goudet J (2002) FSTAT, v. 2.9.3.2. http://www.unil.ch/izea/softwares/fstat.html (February 5, 2002).

$R$ Development Core Team. http://www.r-project.org (January 4, 2006).

Tassel software, v. 1.9.6. http://www.maizegenetics.net (December 2, 2006).

van Hintum TJL, Brown AHD, Spillane C and Hodgkin T (2000) Core collections of plant genetic resources. http://www.bioversityinternational.org/publications/pubfile.asp?ID_PUB $=614$ (December 2, 2006).

\section{Supplementary Material}

The following online material is available for this article:

Table S1. Identification of ERiCC accessions, their origin and common name.

Table S2. Identification and information on SSR Markers used for ERiCC evaluation

This material is made available as part of the online article from http://www.scielo.br.gmb.

Associate Editor: Everaldo Gonçalves de Barros

License information: This is an open-access article distributed under the terms of the Creative Commons Attribution License, which permits unrestricted use, distribution, and reproduction in any medium, provided the original work is properly cited. 
Supplemental Table 1. Identification of the ERiCC accessions, their origin and common name.

\begin{tabular}{|c|c|c|c|c|}
\hline & $\begin{array}{l}\text { CNPAF Germplasm Bank } \\
\text { Identification Number }\end{array}$ & $\begin{array}{l}\text { Cultivation } \\
\text { System }\end{array}$ & Origin $^{* *}$ & Common Name \\
\hline 1 & CNA0000082 & $\mathrm{L}$ & Suriname & AWINI \\
\hline 2 & CNA0000122 & $\mathrm{L}$ & India & ARC-10666 \\
\hline 3 & CNA0000586 & $\mathrm{L}$ & Sri Lanka & BG 090-2 \\
\hline 4 & CNA0000692 & L & India & BKN 6820-6-3-2 \\
\hline 5 & CNA0000754 & L & Peru & CHANCAY \\
\hline 6 & CNA0000798 & $\mathrm{L}$ & Colombia & CICA 4 \\
\hline 7 & CNA0000923 & L & Mexico & C 79-272-4-1-2-3-10 \\
\hline 8 & CNA0000950 & $\mathrm{L}$ & India & IET 0355 \\
\hline 9 & CNA0000952 & $\mathrm{L}$ & Pakistan & CR 36-148 \\
\hline 10 & CNA0001419 & $\mathrm{L}$ & Colombia & COLOMBIA 1 \\
\hline 11 & CNA0001420 & $\mathrm{L}$ & Colombia & CARREON \\
\hline 12 & CNA0001423 & L & Colombia & TAPURIPA-161 \\
\hline 13 & CNA0001467 & L & India & IET 2881 \\
\hline 14 & CNA0002222 & L & Lao & KH.YOUANE (V.T.A 13) \\
\hline 15 & CNA0002246 & L & Lao & KH.NGANH TAMAY (SVA 33) \\
\hline 16 & CNA0002253 & L & Lao & KH.KHAO BAY (VT-A 25) \\
\hline 17 & CNA0002258 & $\mathrm{L}$ & Thailand & KU 56-3 \\
\hline 18 & CNA0002293 & L & Thailand & KU 94-2 \\
\hline 19 & CNA0002416 & L & Liberia & LAC 12 \\
\hline 20 & CNA0002437 & $\mathrm{L}$ & Liberia & LAC 28 \\
\hline 21 & CNA0002480 & L & Cameroon & M 40 \\
\hline 22 & CNA0002482 & $\mathrm{L}$ & Cameroon & M 44 \\
\hline 23 & CNA0002529 & L & Philippines & MEHR \\
\hline 24 & CNA0002672 & L & Thailand & NAHNG PAYA 132 \\
\hline 25 & CNA0002871 & L & Portugal & RIZZOTO 159 \\
\hline 26 & CNA0003195 & L & Egypt & GZ 944-5-2-2 \\
\hline 27 & CNA0003196 & $\mathrm{L}$ & Egypt & GZ 809-4-1-2 \\
\hline 28 & CNA0003005 & $U$ & India & 110281 \\
\hline 29 & CNA0003241 & $\mathrm{L}$ & India & PAU 41-306-2-1-PR 405 \\
\hline 30 & CNA0003411 & L & Colombia & CICA 8 \\
\hline 31 & CNA0003417 & $\mathrm{L}$ & Japan & PI 294351 \\
\hline 32 & CNA0003446 & L & Philippines & IR 34 \\
\hline 33 & CNA0003452 & L & - & CHIANUNG SEN 25 \\
\hline
\end{tabular}




\begin{tabular}{|c|c|c|c|c|}
\hline & $\begin{array}{l}\text { CNPAF Germplasm Bank } \\
\text { Identification Number }\end{array}$ & $\begin{array}{l}\text { Cultivation } \\
\text { System }\end{array}$ & Origin $^{\star *}$ & Common Name \\
\hline 34 & CNA0003569 & $\mathrm{L}$ & India & KAU 2110 \\
\hline 35 & CNA0003591 & L & India & TNAU 2686-1 \\
\hline 36 & CNA0003602 & L & India & UPR $79-23$ \\
\hline 37 & CNA0003665 & $\mathrm{L}$ & Taiwan & KAOHSIUNG SEN YU 104 \\
\hline 38 & CNA0003668 & L & Philippines & MTU 7029 \\
\hline 39 & CNA0004308 & L & USA & CAROLINA SP 407 \\
\hline 40 & CNA0004552 & $\bar{L}$ & Colombia & CR 1113 \\
\hline 41 & CNA0004566 & L & Colombia & METICA 1 \\
\hline 42 & CNA0004576 & L & Colombia & ZENIT \\
\hline 43 & CNA0004579 & $\mathrm{L}$ & Colombia & CAMPONI \\
\hline 44 & CNA0004625 & $\mathrm{L}$ & Colombia & TETEP \\
\hline 45 & CNA0004629 & L & Philippines & IR 50 \\
\hline 46 & CNA0005014 & L & China & WU $10 \mathrm{~B}$ \\
\hline 47 & CNA0005015 & $\mathrm{L}$ & China & YAR AI ZHAO B \\
\hline 48 & CNA0005016 & L & China & ZHENSHAN 97 A \\
\hline 49 & CNA0005477 & L & China & K ASKHAM 36/14 \\
\hline 50 & CNA0005478 & $\mathrm{L}$ & China & SZU MAIO \\
\hline 51 & CNA0005853 & L & Russia & WIR 5621 \\
\hline 52 & CNA0006910 & L & Indonesia & MANINJAU \\
\hline 53 & CNA0006943 & $\mathrm{L}$ & Philippines & IR 54 R \\
\hline 54 & CNA0006955 & L & Italy & KORAL \\
\hline 55 & CNA0006961 & L & Italy & VITRO \\
\hline 56 & CNA0007408 & L & Colombia & WC 0144 \\
\hline 57 & - & L & Suriname & ELONI \\
\hline 58 & - & L & Suriname & CIWINI \\
\hline 59 & - & L & Suriname & CESWONI \\
\hline 60 & - & L & Philippines & IR8 \\
\hline 61 & - & $\mathrm{L}$ & Philippines & IR36 \\
\hline 62 & - & L & USA & LEBONNET \\
\hline 63 & - & L & India & BASMATI 370 \\
\hline 64 & - & L & Japan & NOURIN MOCHI \\
\hline 65 & - & L & Japan & MINAMI HATA MOCHI \\
\hline 66 & - & L & Japan & TOMOE MOCHI \\
\hline 67 & - & L & Japan & MOGAMI CHIKANARI \\
\hline 68 & - & L & Colombia & ORYZICA LHANOS4 \\
\hline 69 & - & L & Colombia & ORYZICA 1 \\
\hline 70 & - & L & Colombia & CICA 7 \\
\hline 71 & - & L & Colombia & CICA 9 \\
\hline 72 & - & L & Philippines & HUAN-SEN-GO \\
\hline 73 & - & $\mathrm{L}$ & - & 5287 \\
\hline 74 & - & $\mathrm{L}$ & - & RAMTULASI \\
\hline 75 & CNA0000482 & $U$ & USA & BLUEBONNET \\
\hline 76 & CNA0001006 & U & USA & DAWN \\
\hline 77 & CNA0002524 & U & France & MOROBEREKAN \\
\hline 78 & CNA0003287 & $U$ & France & IREM 123-2-1 \\
\hline 79 & CNA0003288 & U & France & IREM 293-B \\
\hline
\end{tabular}




\begin{tabular}{|c|c|c|c|c|}
\hline & $\begin{array}{l}\text { CNPAF Germplasm Bank } \\
\text { Identification Number }\end{array}$ & $\begin{array}{l}\text { Cultivation } \\
\text { System* }^{*}\end{array}$ & Origin $* *$ & Common Name \\
\hline 80 & CNA0003289 & $\mathrm{U}$ & France & IREM 247 \\
\hline 81 & CNA0003362 & $U$ & France & IRAT 142 \\
\hline 82 & CNA0003375 & $U$ & France & IRAT 13 \\
\hline 83 & CNA0003395 & U & France & IRAT 141 \\
\hline 84 & CNA0003397 & U & France & IRAT 144 \\
\hline 85 & CNA0003403 & $U$ & Nigeria & TOX 490-3-108-D1-B-B \\
\hline 86 & CNA0004193 & U & France & IREM 656 \\
\hline 87 & CNA0004428 & $U$ & France & N.7384 [RPL X DANIELA] \\
\hline 88 & CNA0004463 & U & France & N.7441 [CA 435 X TAINUNG CHUEN 2] \\
\hline 89 & CNA0004480 & $U$ & France & IRAT 124 \\
\hline 90 & CNA0004487 & U & France & MAKOUTA \\
\hline 91 & CNA0004543 & U & Nigeria & TOX 1012-12-3-1 \\
\hline 92 & CNA0004617 & $U$ & Nigeria & TOX 1011-4-2 \\
\hline 93 & CNA0004640 & $U$ & Nigeria & TOX 1785-19-18 \\
\hline 94 & CNA0004697 & $\mathrm{U}$ & France & N.2583 \\
\hline 95 & CNA0004752 & $U$ & France & IRAT 122 \\
\hline 96 & CNA0004759 & $U$ & Nigeria & TOX 514-16-101-1 \\
\hline 97 & CNA0004788 & $\mathrm{U}$ & Nigeria & TOX 503-4-115-B-B \\
\hline 98 & CNA0004796 & $U$ & Nigeria & TOX 516-28-10B-D2-B-B \\
\hline 99 & CNA0005277 & $U$ & Nigeria & TOX $1858-114$ \\
\hline 100 & CNA0005326 & $U$ & Nigeria & TOX 1780-8-5 \\
\hline 101 & CNA0005334 & U & Nigeria & TOX 1871-29 \\
\hline 102 & CNA0005358 & $U$ & Nigeria & TOX 1858-101 \\
\hline 103 & CNA0005970 & $U$ & Nigeria & FAROX 299 \\
\hline 104 & CNA0005972 & $U$ & Nigeria & FAROX 301 \\
\hline 105 & CNA0005994 & U & Nigeria & TOX 995-208-1-101 \\
\hline 106 & CNA0006034 & $U$ & Nigeria & ITA 150 \\
\hline 107 & CNA0006035 & $U$ & Nigeria & ITA 225 \\
\hline 108 & CNA0006572 & U & France & IREM 195 \\
\hline 109 & CNA0006574 & $U$ & France & IRAT 112 \\
\hline 110 & CNA0006940 & $U$ & USA & LEMONT \\
\hline 111 & CNA0006941 & U & USA & NEW BONNET \\
\hline 112 & CNA0008092 & U & France & L 141 \\
\hline 113 & CNA0008093 & $U$ & France & L 285 \\
\hline 114 & CNA0008411 & U & USA & BLUE BELLE \\
\hline 115 & CNA0008412 & $U$ & USA & BLUEBONNET 50 \\
\hline 116 & CNA0008432 & $U$ & USA & LACASSINE \\
\hline 117 & CNA0008545 & $U$ & Colombia & CT 11216-10-12-B-BRM-10 \\
\hline 118 & CNA0009102 & U & Colombia & CT10006-7-2-M-5-1P-3 \\
\hline 119 & CNA0009113 & U & Colombia & CT10037-9-4-M-1-1P-2-M \\
\hline 120 & CNA0009115 & $U$ & Colombia & CT11632-3-3-M \\
\hline 121 & CNA0009123 & U & Colombia & CT11891-3-3-3-M \\
\hline 122 & CNA0009124 & U & Colombia & CT13364-7-1 \\
\hline 123 & CNA0009139 & $U$ & Colombia & CT13366-15-4 \\
\hline 124 & CNA0009154 & U & Colombia & CT13370-2-M \\
\hline
\end{tabular}




\begin{tabular}{|c|c|c|c|c|}
\hline & $\begin{array}{l}\text { CNPAF Germplasm Bank } \\
\text { Identification Number }\end{array}$ & $\begin{array}{l}\text { Cultivation } \\
\text { System }\end{array}$ & Origin $^{\star *}$ & Common Name \\
\hline 125 & CNA0009197 & $U$ & Colombia & CT13377-8-4 \\
\hline 126 & CNA0009199 & $U$ & Colombia & CT13381-1-3 \\
\hline 127 & CNA0009223 & $U$ & Colombia & CT13569-5-7 \\
\hline 128 & CNA0009227 & $U$ & Colombia & CT13570-3-2 \\
\hline 129 & CNA0009240 & $U$ & Colombia & CT13572-6-2 \\
\hline 130 & CNA0009280 & $U$ & Colombia & CT13573-11-2 \\
\hline 131 & CNA0009319 & $U$ & Colombia & CT13579-3-4 \\
\hline 132 & CNA0009364 & $U$ & Colombia & CT13581-5-2 \\
\hline 133 & CNA0009415 & $U$ & Colombia & CT13582-11-4 \\
\hline 134 & CNA0009561 & $U$ & Colombia & CT13584-12-9 \\
\hline 135 & CNA0009591 & $U$ & Colombia & CT13585-12-3 \\
\hline 136 & & $U$ & - & B6149F-MR-19 \\
\hline 137 & - & $U$ & Philippines & В8503-ТВ-19-В-3 \\
\hline 138 & - & $U$ & - & BR4742-B-19-23 \\
\hline 139 & - & $U$ & India & CUTACK 4 \\
\hline 140 & - & U & Philippines & IR65907-188-1-B \\
\hline 141 & - & $U$ & France & IRAT 10 \\
\hline 142 & - & $U$ & Philippines & KATAKTARA \\
\hline 143 & - & U & Philippines & TB154E-TB-2 \\
\hline 144 & - & $U$ & Philippines & TB47H-MR-11-51-3 \\
\hline 145 & - & $U$ & Philippines & YN1905-UUL-62 \\
\hline 146 & - & $U$ & Philippines & YN906-UUL 65 \\
\hline 147 & - & $U$ & China & YUNLU N 1 \\
\hline 148 & - & $U$ & China & YUNLU N 7 \\
\hline 149 & - & L & EMBRAPA-CNPAF/ Brazil & RS16PL12-35-1-B \\
\hline 150 & - & L & EMBRAPA-CNPAF/ Brazil & RS16PL1-34-4-B \\
\hline 151 & - & $\mathrm{L}$ & EMBRAPA-CNPAF/ Brazil & RS16PL5-12-6-B \\
\hline 152 & - & L & EMBRAPA-CNPAF/ Brazil & RS16PL12-10-1-B \\
\hline 153 & CNA0001416 & L & EMBRAPA-CNPAF/ Brazil & IPSL 0574 \\
\hline 154 & CNA0001117 & L & EEPG/ Brazil & EEPG-1-169 \\
\hline 155 & - & L & EMBRAPA-CPACT/ Brazil & BRS AGRISUL \\
\hline 156 & - & L & EMBRAPA-CPACT/ Brazil & BRS BOJURU \\
\hline 157 & - & L & EMBRAPA-CNPAF/ Brazil & DIAMANTE \\
\hline 158 & - & L & EMBRAPA-CNPAF/ Brazil & BRS FORMOSO \\
\hline 159 & - & L & EMBRAPA-CNPAF/ Brazil & MARAJO \\
\hline 160 & - & L & EMBRAPA-CNPAF/ Brazil & BRS JABURU \\
\hline 161 & - & L & EMBRAPA-CNPAF/ Brazil & BRS BIGUA \\
\hline 162 & - & L & EMBRAPA-CNPAF/ Brazil & RIO GRANDE \\
\hline 163 & - & L & EPAGRI/ Brazil & EPAGRI 107 \\
\hline 164 & - & L & EPAGRI/ Brazil & EPAGRI 108 \\
\hline 165 & - & L & EPAGRI/ Brazil & SCS 111 \\
\hline 166 & - & L & EPAGRI/ Brazil & $\operatorname{SCS} 112$ \\
\hline 167 & CNA0001337 & L & IPEACO/ Brazil & IPEACO-SL 1969 \\
\hline 168 & CNA0001339 & L & IPEACO/ Brazil & IPEACO-SL 0769 \\
\hline 169 & CNA0001344 & L & IPEACO/ Brazil & IPEACO-SL 1469 \\
\hline
\end{tabular}




\begin{tabular}{|c|c|c|c|c|}
\hline & $\begin{array}{l}\text { CNPAF Germplasm Bank } \\
\text { Identification Number }\end{array}$ & $\begin{array}{l}\text { Cultivation } \\
\text { System }\end{array}$ & Origin $^{* *}$ & Common Name \\
\hline 170 & CNA0001407 & $\mathrm{L}$ & IPEACO/ Brazil & IPSL 2070 \\
\hline 171 & CNA0001413 & L & IPEACO/ Brazil & IPSL 0970 \\
\hline 172 & CNA0001414 & L & IPEACO/ Brazil & IPSL 0570 \\
\hline 173 & CNA0001106 & L & IRGA/ Brazil & EEA 405 \\
\hline 174 & CNA0001107 & L & IRGA/ Brazil & EEA 401 \\
\hline 175 & CNA0001108 & L & IRGA/ Brazil & EEA 404 \\
\hline 176 & CNA0001109 & L & IRGA/ Brazil & EEA 406 \\
\hline 177 & - & L & IRGA/ Brazil & IRGA 409 \\
\hline 178 & - & $\mathrm{L}$ & IRGA/ Brazil & IRGA 413 \\
\hline 179 & - & $\mathrm{L}$ & IRGA/ Brazil & IRGA 416 \\
\hline 180 & - & L & IRGA/ Brazil & IRGA 417 \\
\hline 181 & - & L & IRGA/ Brazil & IRGA 418 \\
\hline 182 & - & $\mathrm{L}$ & IRGA/ Brazil & IRGA 419 \\
\hline 183 & - & L & IRGA/ Brazil & IRGA 420 \\
\hline 184 & CNA0006129 & $\mathrm{L}$ & EMPASC/ Brazil & EMPASC 103 \\
\hline 185 & CNA0006130 & L & EMPASC/ Brazil & EMPASC 104 \\
\hline 186 & CNA0001118 & $U$ & EEPG/ Brazil & EEPG-1-269-FURNAS \\
\hline 187 & CNA0000963 & U & IPEACO/ Brazil & AMARELAO X GUEDES \\
\hline 188 & CNA0000969 & U & IPEACO/ Brazil & HONDURAS X MATAO \\
\hline 189 & CNA0000976 & $U$ & IPEACO/ Brazil & SATURNO X PRATAO PRECOCE \\
\hline 190 & CNA0000994 & U & IPEACO/ Brazil & ESAV X MATAO \\
\hline 191 & CNA0001347 & U & IPEACO/ Brazil & IPEACO-SL 2270 \\
\hline 192 & CNA0001350 & $U$ & IPEACO/ Brazil & IPEACO-SL 1970 \\
\hline 193 & CNA0004098 & $U$ & EMBRAPA-CNPAF/ Brazil & XINGU \\
\hline 194 & CNA0004120 & $U$ & EMBRAPA-CNPAF/ Brazil & RIO PARAGUAY \\
\hline 195 & CNA0004121 & $U$ & EMBRAPA-CNPAF/ Brazil & GUARANI \\
\hline 196 & CNA0004141 & U & EMBRAPA-CNPAF/ Brazil & TRIUNFO \\
\hline 197 & CNA0004172 & $U$ & EMBRAPA-CNPAF/ Brazil & GUAPORE \\
\hline 198 & CNA0004206 & U & EMBRAPA-CNPAF/ Brazil & ARAGUAIA \\
\hline 199 & CNA0004748 & $U$ & EMBRAPA-CNPAF/ Brazil & CUIABANA \\
\hline 200 & CNA0005180 & $U$ & EMBRAPA-CNPAF/ Brazil & TANGARA \\
\hline 201 & CNA0006187 & U & EMBRAPA-CNPAF/ Brazil & CAIAPO \\
\hline 202 & CNA0006701 & U & EMBRAPA-CNPAF/ Brazil & CARAJAS \\
\hline 203 & CNA0007024 & $U$ & EMBRAPA-CNPAF/ Brazil & CNAX 1503-12-9-4-B \\
\hline 204 & CNA0007119 & U & EMBRAPA-CNPAF/ Brazil & AIMORE \\
\hline 205 & CNA0007706 & U & EMBRAPA-CNPAF/ Brazil & CONFIANCA \\
\hline 206 & CNA0008070 & $U$ & EMBRAPA-CNPAF/ Brazil & PRIMAVERA \\
\hline 207 & CNA0008711 & U & EMBRAPA-CNPAF/ Brazil & SOBERANA \\
\hline 208 & CNA0005673 & $U$ & IAC/ Brazil & IAC 81-176 \\
\hline 209 & CNA0005901 & U & IAC/ Brazil & URUCUI \\
\hline 210 & CNA0006170 & U & IAC/ Brazil & LS 85-125 \\
\hline 211 & CNA0006174 & $U$ & IAC/ Brazil & LS $85-158$ \\
\hline 212 & CNA0007799 & $U$ & IAC/ Brazil & IAC 1191 \\
\hline 213 & CNA0006406 & $U$ & IAC/ Brazil & LS 86-68 \\
\hline 214 & CNA0004168 & U & IAPAR/ Brazil & L 80-68 \\
\hline
\end{tabular}




\begin{tabular}{|c|c|c|c|c|}
\hline & $\begin{array}{l}\text { CNPAF Germplasm Bank } \\
\text { Identification Number }\end{array}$ & $\begin{array}{l}\text { Cultivation } \\
\text { System }\end{array}$ & Origin $^{\star *}$ & Common Name \\
\hline 215 & CNA0005672 & $\mathrm{U}$ & IAPAR/ Brazil & L 82-192 \\
\hline 216 & CNA0006666 & $U$ & IAPAR/ Brazil & A12-286-1-1 \\
\hline 217 & CNA0006672 & $U$ & IAPAR/ Brazil & A8-204-1-1 \\
\hline 218 & CNA0008309 & $U$ & IAPAR/ Brazil & L 92-342 \\
\hline 219 & CNA0006413 & $U$ & IAPAR/ Brazil & L 85-20 \\
\hline 220 & CNA0006422 & $U$ & IAPAR/ Brazil & IAPAR L 99-98 \\
\hline 221 & CNA0005650 & $U$ & IPEACO/ Brazil & IPEACO 11-P \\
\hline 222 & CNA0005660 & $U$ & IPEACO/ Brazil & IPEACO 77-P \\
\hline 223 & CNA0003281 & $U$ & Brazil & IRAT 177 \\
\hline 224 & CNA0005342 & $U$ & Brazil & RIO VERDE \\
\hline 225 & CNA0002123 & $U$ & EEPG/ Brazil & JAPONES X PRAIANA \\
\hline 226 & - & $U$ & IAC/ Brazil & IAC 201 \\
\hline 227 & - & $U$ & IAC/ Brazil & IAC 202 \\
\hline 228 & - & $U$ & IAC/ Brazil & IAC 165 \\
\hline 229 & - & $U$ & IAPAR/ Brazil & IAPAR 9 \\
\hline 230 & - & $U$ & IAPAR/ Brazil & IAPAR 62 \\
\hline 231 & - & U & IAPAR/ Brazil & IAPAR 63 \\
\hline 232 & CNA0003490 & $U$ & Brazil & MEARIN \\
\hline 233 & CNA0004078 & $U$ & Brazil & - \\
\hline 234 & CNA0004243 & U & Brazil & - \\
\hline 235 & CNA0005975 & $U$ & Brazil & - \\
\hline 236 & CNA0006030 & $U$ & EMBRAPA-CNPAF/ Brazil & - \\
\hline 237 & CNA0007425 & $U$ & EMBRAPA-CNPAF/ Brazil & CANASTRA \\
\hline 238 & CNA0007937 & $U$ & EMBRAPA-CNPAF/ Brazil & PROGRESSO \\
\hline 239 & CNA0008172 & $U$ & EMBRAPA-CNPAF/ Brazil & BONANCA \\
\hline 240 & CNA0008305 & $U$ & EMBRAPA-CNPAF/ Brazil & CARISMA \\
\hline 241 & CNA0008533 & $U$ & EMBRAPA-CNPAF/ Brazil & MARAVILHA \\
\hline 242 & CNA0008540 & $U$ & EMBRAPA-CNPAF/ Brazil & TALENTO \\
\hline
\end{tabular}

${ }^{*} \mathrm{~L}=$ lowland accessions $; \mathrm{U}=$ upland accessions. For comparison with other studies, the lowland accessions used in this study were considered as indica and the upland accessions, as japonica [Khush GS (1997) Origin, dispersal, cultivation and variation of rice. Plant Molecular Biology 35:25-34].

** EMBRAPA - CNPAF = Empresa Brasileira de Pesquisa Agropecuária - Centro Nacional de Pesquisa (Brazil); IAC = Instituto Agronômico de Campinas (Brazil); IPEACO = Instituto de Pesquisa Agropecuária do Centro Oeste (Brazil); IAPAR = Instituto Agronômico do Paraná (Brazil); EMPASC = Empresa de Pesquisa Agropecuária de Santa Catarina (Brazil); EEPG = Estação Experimental de Ponta Grossa (Brazil); IRGA = Instituto Rio Grandense do Arroz (Brazil); EPAGRI = Empresa de Pesquisa Agropecuária e Extensão Rural de Santa Catarina (Brazil) 
Supplemental Table 2. SSR Markers used for the evaluation of the ERiCC accessions (Data on "Marker concentration for multiplexed PCR", "Missing data", "Number of alleles" and "PIC" were obtained in this study).

\begin{tabular}{|c|c|c|c|c|c|c|c|c|c|c|}
\hline Panel & SSR Marker & $\begin{array}{l}\text { Marker concentration for } \\
\text { multiplexed PCR ( } \mathrm{nM})\end{array}$ & Missing data (\%) & Fluorochrome & $\begin{array}{l}\text { Allele size } \\
\text { range (bp) }\end{array}$ & $\begin{array}{c}\text { Number of } \\
\text { alleles }\end{array}$ & PIC & Motif & Chromosome & References ${ }^{\star \star}$ \\
\hline \multirow{2}{*}{1} & RM229 & 129 & 5.9 & HEX & $106-131$ & 11 & 0.83 & $(\mathrm{TC})_{11}(\mathrm{CT})_{5} \mathrm{C}_{3}(\mathrm{CT})_{5}$ & 11 & Chen et al. (1997) \\
\hline & RM207 & 129 & 3.1 & FAM & $84-158$ & 23 & 0.86 & $(\mathrm{CT})_{25}$ & 2 & Chen et al. (1997) \\
\hline \multirow{4}{*}{2} & RM222* & 129 & 10 & FAM & $199-215$ & 12 & 0.72 & $(\mathrm{CT})_{18}$ & 10 & Chen et al. (1997) \\
\hline & RM1 & 71.67 & 0.8 & FAM & $76-119$ & 23 & 0.75 & $(A G)_{26}$ & 1 & Panaud et al. (1996) \\
\hline & RM248 & 150 & 4.1 & HEX & $80-104$ & 11 & 0.81 & $(\mathrm{CT})_{25}$ & 7 & Chen et al. (1997) \\
\hline & RM38 & 71.67 & 5.7 & HEX & $246-278$ & 18 & 0.86 & $(\mathrm{GA})_{16}$ & 8 & Chen et al. (1997) \\
\hline \multirow{2}{*}{3} & RM5 & 71.67 & 1.8 & FAM & $109-133$ & 9 & 0.73 & $(\mathrm{GA})_{14}$ & 1 & Panaud et al. (1996) \\
\hline & RM253 & 71.67 & 9.8 & HEX & $89-119$ & 11 & 0.75 & $(\mathrm{GA})_{25}$ & 6 & Chen et al. (1997) \\
\hline \multirow{2}{*}{4} & RM11 & 71.67 & 3.6 & HEX & $123-143$ & 11 & 0.78 & $(\mathrm{GA})_{17}$ & 7 & Panaud et al. (1996) \\
\hline & RM13* & 129 & 4.6 & FAM & $129-164$ & 15 & 0.72 & $\left.(\mathrm{GA})_{6}-\mathrm{GA}\right)_{16}$ & 5 & Panaud et al. (1996) \\
\hline \multirow{3}{*}{5} & RM252 & 129 & 11 & FAM & $193-277$ & 23 & 0.62 & $(\mathrm{CT})_{19}$ & 4 & Chen et al. (1997) \\
\hline & RM277 & 129 & 1.8 & FAM & $110-126$ & 8 & 0.58 & $(\mathrm{GA})_{11}$ & 12 & Temnykh et al. (2000) \\
\hline & RM204 & 129 & 6.9 & HEX & $106-194$ & 32 & 0.87 & $(\mathrm{CT})_{44}$ & 6 & Chen et al. (1997) \\
\hline \multirow{2}{*}{6} & RM231 & 129 & 10.5 & FAM & $170-196$ & 10 & 0.78 & $(\mathrm{CT})_{16}$ & 3 & Chen et al. (1997) \\
\hline & RM304 & 129 & 10 & HEX & $82-198$ & 21 & 0.84 & $(\mathrm{GT})_{2}(\mathrm{AT})_{10}(\mathrm{GT})_{33}$ & 10 & Temnykh et al. (2000) \\
\hline
\end{tabular}




\begin{tabular}{|c|c|c|c|c|c|c|c|c|c|c|}
\hline Panel & $\begin{array}{c}\text { SSR } \\
\text { Marker }\end{array}$ & $\begin{array}{l}\text { Marker concentration for } \\
\text { multiplexed PCR ( } \mathrm{nM})\end{array}$ & Missing data (\%) & Fluorochrome & $\begin{array}{l}\text { Allele size } \\
\text { range (bp) }\end{array}$ & $\begin{array}{c}\text { Number of } \\
\text { alleles }\end{array}$ & PIC & Motif & Chromosome & References ${ }^{\star *}$ \\
\hline \multirow{2}{*}{7} & OG17 & 71.67 & 2.3 & FAM & $114-180$ & 24 & 0.77 & $(\mathrm{CT})_{24}$ & 2 & Brondani et al. (2001) \\
\hline & OG44* & 71.67 & 2.8 & HEX & $152-182$ & 15 & 0.80 & $(\mathrm{CT})_{4}-23 \mathrm{bp}-(\mathrm{CT})_{22}-(\mathrm{GT})_{4}-(\mathrm{GC})_{6}$ & 3 & Brondani et al. (2001) \\
\hline \multirow{2}{*}{8} & OG106* & 129 & 10 & FAM & $200-250$ & 22 & 0.90 & $(\mathrm{CT})_{27}$ & 9 & Brondani et al. (2001) \\
\hline & 4879 & 129 & 9.5 & HEX & $108-150$ & 10 & 0.80 & $(\mathrm{AAT})_{8}$ & 4 & Rangel (2005) \\
\hline \multirow{2}{*}{9} & $4653^{*}$ & 129 & 3.9 & FAM & $80-170$ & 19 & 0.85 & $(\mathrm{AAG})_{25}$ & 12 & Rangel (2005) \\
\hline & RM224 & 129 & 4.1 & HEX & $124-158$ & 10 & 0.81 & $(A A G)_{8}-(A G)_{13}$ & 11 & Chen et al. (1997) \\
\hline \multirow{2}{*}{10} & RM223* & 129 & 3.6 & FAM & $139-163$ & 15 & 0.64 & $(\mathrm{CT})_{25}$ & 8 & Chen et al. (1997) \\
\hline & RM257 & 71.67 & 4.1 & HEX & $130-192$ & 22 & 0.90 & $(\mathrm{CT})_{24}$ & 9 & Chen et al. (1997) \\
\hline \multirow{2}{*}{11} & OG61* & 129 & 2.3 & FAM & $96-152$ & 28 & 0.88 & $(\mathrm{CT})_{18}$ & 5 & Brondani et al. (2001) \\
\hline & RM234 & 129 & 0.8 & HEX & $126-156$ & 13 & 0.78 & $(\mathrm{CT})_{25}$ & 7 & Chen et al. (1997) \\
\hline \multirow{3}{*}{12} & RM103 & 198 & 3.0 & FAM & $300-350$ & 4 & 0.64 & $(\mathrm{GAA})_{5}$ & 6 & Temnykh et al. (2000) \\
\hline & RM334 & 258 & 3.3 & FAM & $120-210$ & 14 & 0.86 & $(\mathrm{CTT})_{20}$ & 5 & Temnykh et al. (2000) \\
\hline & RM309 & 198 & 1.9 & HEX & $150-180$ & 14 & 0.79 & $(\mathrm{GT})_{13}$ & 12 & Temnykh et al. (2000) \\
\hline \multirow{2}{*}{13} & RM286 & 138 & 2.1 & FAM & $80-140$ & 14 & 0.84 & $(\mathrm{GA})_{16}$ & 11 & Temnykh et al. (2000) \\
\hline & RM276 & 180 & 3.9 & HEX & $75-160$ & 17 & 0.84 & $(\mathrm{AG})_{8}-\mathrm{A}_{3}-(\mathrm{GA})_{33}$ & 6 & Temnykh et al. (2000) \\
\hline
\end{tabular}




\begin{tabular}{|c|c|c|c|c|c|c|c|c|c|c|}
\hline Panel & SSR Marker & $\begin{array}{l}\text { Marker concentration for } \\
\text { multiplexed PCR }(\mathrm{nM})\end{array}$ & Missing data (\%) & Fluorochrome & $\begin{array}{l}\text { Allele size } \\
\text { range (bp) }\end{array}$ & $\begin{array}{l}\text { Number of } \\
\text { alleles }\end{array}$ & PIC & Motif & Chromosome & References ${ }^{\star \star}$ \\
\hline \multirow{4}{*}{14} & RM125 & 129 & 0.3 & FAM & $100-150$ & 13 & 0.58 & $(\mathrm{GCT})_{8}$ & 7 & Temnykh et al. (2000) \\
\hline & RM171 & 71.67 & 7.5 & FAM & $310-344$ & 8 & 0.59 & $(\text { GATG })_{5}$ & 10 & Akagi et al. (1996) \\
\hline & RM484 & 71.67 & 7.5 & HEX & $290-300$ & 3 & 0.53 & $(\mathrm{AT})_{9}$ & 10 & Temnykh et al. (2001) \\
\hline & RM341 & 71.67 & 1.0 & HEX & $110-180$ & 19 & 0.76 & $(\mathrm{CTT})_{20}$ & 2 & Temnykh et al. (2000) \\
\hline \multirow{2}{*}{15} & RM169* & 258 & 0.3 & FAM & $150-200$ & 14 & 0.75 & $(\mathrm{GA})_{12}$ & 5 & Temnykh et al. (2000) \\
\hline & RM216 & 129 & 0.5 & HEX & $120-155$ & 10 & 0.81 & $(\mathrm{CT})_{18}$ & 10 & Chen et al. (1997) \\
\hline \multirow{2}{*}{16} & RM152 & 258 & 0.3 & FAM & $150-180$ & 10 & 0.58 & $(\mathrm{GGC})_{10}$ & 8 & Akagi et al. (1996) \\
\hline & RM267 & 129 & 0.3 & HEX & $125-175$ & 11 & 0.49 & $(\mathrm{GA})_{21}$ & 5 & Temnykh et al. (2000) \\
\hline \multirow{2}{*}{17} & RM264 & 180 & 3.3 & FAM & 125-195 & 22 & 0.83 & $(\mathrm{GA})_{27}$ & 8 & Temnykh et al. (2000) \\
\hline & RM263 & 138 & 0.8 & HEX & $164-220$ & 13 & 0.80 & $(\mathrm{CT})_{34}$ & 2 & Chen et al. (1997) \\
\hline \multirow{2}{*}{18} & RM335 & 180 & 3.3 & FAM & $100-170$ & 26 & 0.90 & $(\mathrm{CTT})_{25}$ & 4 & Temnykh et al. (2000) \\
\hline & RM287 & 138 & 8.0 & HEX & $90-140$ & 12 & 0.75 & $(\mathrm{GA})_{21}$ & 11 & Temnykh et al. (2000) \\
\hline \multirow{3}{*}{19} & RM151 & 258 & 2.3 & FAM & $197-220$ & 7 & 0.74 & $(\mathrm{TA})_{23}$ & 1 & Akagi et al. (1996) \\
\hline & RM271 & 138 & 4.3 & FAM & $75-125$ & 6 & 0.80 & $(G A)_{15}$ & 10 & Temnykh et al. (2000) \\
\hline & RM336* & 129 & 3.3 & HEX & $100-200$ & 6 & 0.79 & $(\mathrm{CTT})_{18}$ & 7 & Temnykh et al. (2000) \\
\hline
\end{tabular}




\begin{tabular}{|c|c|c|c|c|c|c|c|c|c|c|}
\hline Panel & SSR Marker & $\begin{array}{l}\text { Marker concentration for } \\
\text { multiplexed PCR (nM) }\end{array}$ & Missing Data (\%) & Fluorochrome & $\begin{array}{l}\text { Allele size } \\
\text { range (bp) }\end{array}$ & $\begin{array}{l}\text { Number of } \\
\text { alleles }\end{array}$ & PIC & Motif & Chromosome & References ${ }^{\star *}$ \\
\hline \multirow{2}{*}{20} & RM51 & 270 & 14.0 & FAM & $120-150$ & 9 & 0.77 & $(\mathrm{GA})_{13}$ & 7 & Chen et al. (1997) \\
\hline & RM332 & 129 & 12.0 & HEX & $140-190$ & 6 & 0.62 & $(\mathrm{CTT})_{\left.5^{-}-\mathrm{CTT}\right)_{14}}$ & 11 & Temnykh et al. (2000) \\
\hline \multirow{3}{*}{21} & RM310 & 116.67 & 3.3 & HEX & $80-130$ & 9 & 0.84 & $(\mathrm{GT})_{19}$ & 8 & Temnykh et al. (2000) \\
\hline & RM9 & 100 & 4.5 & FAM & $120-200$ & 14 & 0.80 & $(\mathrm{GA})_{15} \mathrm{GT}(\mathrm{GA})_{2}$ & 1 & Panaud et al. (1996) \\
\hline & RM22* & 132 & 1.3 & HEX & $150-230$ & 7 & 0.55 & $(\mathrm{GA})_{22}$ & 3 & Panaud et al. (1996) \\
\hline \multirow{3}{*}{22} & RM55 & 150 & 3.2 & HEX & $200-245$ & 18 & 0.89 & $(\mathrm{GA})_{17}$ & 3 & Chen et al. (1997) \\
\hline & RM266 & 210 & 8.8 & FAM & $100-150$ & 13 & 0.79 & $(\mathrm{GA})_{19}$ & 2 & Temnykh et al. (2000) \\
\hline & RM278 & 258 & 1.3 & HEX & $120-160$ & 17 & 0.89 & $(\mathrm{GA})_{17}$ & 9 & Temnykh et al. (2000) \\
\hline \multirow{3}{*}{23} & RM85 & 180 & 2.3 & FAM & $80-120$ & 8 & 0.79 & $(\mathrm{TGG})_{5}(\mathrm{TCT})_{12}$ & 3 & Temnykh et al. (2000) \\
\hline & RM117 & 258 & 4.2 & FAM & $190-220$ & 12 & 0.71 & $(A G)_{7}$ & 12 & Temnykh et al. (2000) \\
\hline & RM302 & 180 & 1.3 & HEX & $70-210$ & 8 & 0.82 & $(\mathrm{GT})_{30}(\mathrm{AT})_{8}$ & 1 & Temnykh et al. (2000) \\
\hline \multirow{2}{*}{24} & RM206 & 258 & 7.8 & FAM & $115-210$ & 12 & 0.80 & $(\mathrm{CT})_{21}$ & 11 & Chen et al. (1997) \\
\hline & RM159 & 258 & 3.1 & HEX & $220-280$ & 9 & 0.75 & $(G A)_{19}$ & 5 & Temnykh et al. (2000) \\
\hline \multirow{2}{*}{25} & OG99 & 71.67 & 2.3 & FAM & $110-160$ & 7 & 0.19 & $(\mathrm{CT})_{4} \mathrm{TT}(\mathrm{CT})_{4} \mathrm{CC}(\mathrm{CT})_{3}-16 \mathrm{pb}-(\mathrm{CT})_{8}$ & 3 & Brondani et al. (2001) \\
\hline & OG60 & 71.67 & 0.5 & HEX & $100-160$ & 14 & 0.74 & $(\mathrm{CT})_{21}(\mathrm{TCC})_{2}$ & 4 & Brondani et al. (2001) \\
\hline
\end{tabular}




\begin{tabular}{|c|c|c|c|c|c|c|c|c|c|c|}
\hline Panel & SSR Marker & $\begin{array}{l}\text { Marker concentration for } \\
\text { multiplexed PCR }(\mathrm{nM})\end{array}$ & Missing Data (\%) & Fluorochrome & $\begin{array}{l}\text { Allele size } \\
\text { range (bp) }\end{array}$ & $\begin{array}{l}\text { Number of } \\
\text { alleles }\end{array}$ & PIC & Motif & Chromosome & References ${ }^{\star \star}$ \\
\hline \multirow{2}{*}{26} & RM261 & 138 & 4.5 & FAM & $100-130$ & 15 & 0.59 & $\mathrm{C}_{9}(\mathrm{CT})_{8}$ & 4 & Chen et al. (1997) \\
\hline & RM3 & 210 & 3.2 & HEX & $115-160$ & 4 & 0.70 & $(\mathrm{GA})_{2} \mathrm{GG}(\mathrm{GA})_{25}$ & 6 & Panaud et al. (1996) \\
\hline \multirow{3}{*}{27} & RM220 & 150 & 2.4 & FAM & $90-135$ & 9 & 0.69 & $(\mathrm{CT})_{17}$ & 1 & Chen et al. (1997) \\
\hline & RM280 & 258 & 4.1 & HEX & $140-190$ & 6 & 0.88 & $(\mathrm{GA})_{16}$ & 4 & Temnykh et al. (2000) \\
\hline & RM7 & 210 & 3.0 & FAM & $160-195$ & 15 & 0.85 & $(\mathrm{GA})_{19}$ & 3 & Panaud et al. (1996) \\
\hline \multirow{3}{*}{28} & RM144* & 258 & 9.5 & FAM & $200-250$ & 15 & 0.75 & $(\mathrm{ATT})_{11}$ & 11 & Temnykh et al. (2000) \\
\hline & RM243 & 129 & 4.2 & FAM & $85-130$ & 10 & 0.75 & $(\mathrm{CT})_{18}$ & 1 & Chen et al. (1997) \\
\hline & RM317 & 258 & 5.0 & HEX & $120-180$ & 9 & 0.76 & $(\mathrm{GC})_{4}(\mathrm{GT})_{18}$ & 4 & Temnykh et al. (2000) \\
\hline \multirow{3}{*}{29} & RM190* & 150 & 0.5 & FAM & $100-130$ & 11 & 0.75 & $(\mathrm{CT})_{11}$ & 6 & Akagi et al. (1996) \\
\hline & RM205 & 210 & 0.5 & HEX & $115-170$ & 14 & 0.78 & $(\mathrm{CT})_{25}$ & 9 & Chen et al. (1997) \\
\hline & RM70 & 258 & 11.5 & FAM & $150-215$ & 11 & 0.80 & $(\mathrm{ATT})_{33}$ & 7 & Chen et al. (1997) \\
\hline \multirow{3}{*}{30} & RM14 & 270 & 10.0 & HEX & $160-120$ & 9 & 0.81 & $(\mathrm{GA})_{18}$ & 1 & Panaud et al. (1996) \\
\hline & $5371^{*}$ & 258 & 8.4 & FAM & $150-210$ & 5 & 0.83 & $(\mathrm{GAA})_{14}$ & 12 & Rangel (2005) \\
\hline & RM178 & 258 & 4.3 & HEX & $110-140$ & 8 & 0.69 & $(\mathrm{GA})_{5}(\mathrm{AG})_{8}$ & 5 & Temnykh et al. (2000) \\
\hline \multirow{2}{*}{31} & RM210 & 129 & 1.3 & FAM & $115-175$ & 15 & 0.87 & $(\mathrm{CT})_{23}$ & 8 & Chen et al. (1997) \\
\hline & RM240 & 129 & 0.3 & HEX & $120-160$ & 5 & 0.47 & $(\mathrm{CT})_{21}$ & 2 & Chen et al. (1997) \\
\hline
\end{tabular}




\begin{tabular}{|c|c|c|c|c|c|c|c|c|c|c|}
\hline Panel & $\begin{array}{c}\text { SSR } \\
\text { Marker }\end{array}$ & $\begin{array}{l}\text { Marker concentration for } \\
\text { multiplexed PCR ( } \mathrm{nM})\end{array}$ & Missing Data (\%) & Fluorochrome & $\begin{array}{l}\text { Allele size } \\
\text { range (bp) }\end{array}$ & $\begin{array}{l}\text { Number of } \\
\text { alleles }\end{array}$ & PIC & Motif & Chromosome & References** \\
\hline \multirow{3}{*}{32} & RM161 & 198 & 4.4 & HEX & $150-200$ & 8 & 0.59 & $(A G)_{20}$ & 5 & Temnykh et al. (2000) \\
\hline & RM135 & 198 & 1.3 & FAM & $100-140$ & 5 & 0.55 & $(C G G)_{10}$ & 3 & Akagi et al. (1996) \\
\hline & OG10* & 258 & 0.0 & HEX & $40-130$ & 21 & 0.81 & $(\mathrm{CT})_{29}$ & 9 & Brondani et al. (2001) \\
\hline \multirow{3}{*}{33} & RM30 & 270 & 4.9 & HEX & $70-120$ & 15 & 0.64 & $(\mathrm{AG})_{9} \mathrm{~A}(\mathrm{GA})_{12}$ & 6 & Panaud et al. (1996) \\
\hline & RM154 & 258 & 5.3 & HEX & $140-210$ & 14 & 0.91 & $(G A)_{21}$ & 2 & Akagi et al. (1996) \\
\hline & RM119 & 258 & 7.0 & FAM & $150-185$ & 6 & 0.75 & $(\mathrm{GTC})_{6}$ & 4 & Temnykh et al. (2000) \\
\hline \multirow{2}{*}{34} & RM311 & 270 & 5.0 & HEX & $160-200$ & 8 & 0.74 & $(\mathrm{GT})_{3}(\mathrm{GTAT})_{8}(\mathrm{GT})_{5}$ & 10 & Temnykh et al. (2000) \\
\hline & $\mathrm{RM} 3^{*}$ & 258 & 10.0 & FAM & $168-208$ & 7 & 0.76 & $(G A)_{14}$ & 2 & Chen et al. (1997) \\
\hline \multirow{2}{*}{35} & RM12 & 129 & 2.1 & FAM & $150-190$ & 7 & 0.41 & $(G A)_{21}$ & 12 & Panaud et al. (1996) \\
\hline & RM19 & 258 & 11.0 & HEX & $200-270$ & 11 & 0.72 & $(\text { ATC })_{10}$ & 12 & Panaud et al. (1996) \\
\hline Average & - & - & & - & - & 12.4 & 0.75 & - & - & - \\
\hline
\end{tabular}

${ }^{* *}$ References

Akagi H, Yokozeki Y, Inagaki A, Fujimura T (1996) Microsatellite DNA markers for rice chromosomes. Theor Appl Genet 93: 1071-1077.

Brondani C, Brondani RPV, Rangel PHN, Ferreira ME (2001) Development and mapping of Oryza glumaepatula derived microsatellite markers in the interspecific cross $O$. glumaepatula $\times$ O. sativa. Hereditas 134: 59-71.

Chen X, Temnykh S, Xu Y, Cho YG, McCouch SR (1997) Development of a microsatellite framework map providing genome-wide coverage in rice (Oryza sativa L). Theor Appl Genet 95: 553-567

Panaud O, Chen X, McCouch SR (1996) Development of microsatellite markers and characterization of simple sequence length polymorphism (SSLP) in rice (Oryza sativa L.) Mol Gen Genet 252: 597-607

Rangel, PN. Construção de mapa de ligação e mapeamento de QTLs utilizando marcadores SSRs, ESTs e SNPs em cruzamento interespecífico Oryza glumaepatula X Oryza sativa. Thesis, Universidade Federal de Goiás, 111 pp.

Temnykh S, Park WD, Ayres NM, Cartinhour S, Hauck N, Lipovich L, Cho YG, Ishii T, McCouch SR (2000) Mapping and genome organization of

microsatellite sequences in rice (Oryza sativa L.). Theor Appl Genet 100: 697-712 